\title{
Green building for office interiors: challenges and opportunities
}

\section{Background}

Green interiors are a ramification of green building that refers to efficiently using resources and improving occupant health and productivity. The increased interest in the green building concept resulted in a number of green building standards and rating systems such as LEED (Leadership in Energy and Environmental Design), which help government regulators, building professionals and consumers embrace green building with confidence (Yudelson, 2008). Aiming at the fit-out, renovation and refurbishment of interior spaces, green building rating systems for interiors are launched. For example, LEED for Commercial Interiors (LEED CI) enables project teams, who may not have control over whole building operations, the opportunity to develop indoor spaces that are better for the environment as well as for occupants. Similar green interiors' rating systems are Hong Kong Building Environmental Assessment Method (previously known for BEAM, now BEAM Plus) for Interiors, Singapore Green Mark for Interiors, Australia Green Star for Interiors and so on.

Although research tends to be sceptical about the green building rating system, it is undeniable that these standards or rating systems provide practical methods and guidelines for designing and assessing building performance through a user-friendly checklist. Real estate research repeatedly reported strong business cases for green buildings in the commercial sector, such as lower operation costs and higher market performance (Dermisi, 2009, Fuerst and McAllister, 2009, Kuziemko, 2015, Gou et al., 2013, Hui et al., 2015). The business senses plus governmental policies make the green building revolution swipe across the world in the past two decades. By the end of 2014, more than 7000 building projects covering 1.5 billion gross floor areas applied LEED as the design guideline for sustainability (USGBC, 2014). Among all green building projects, the contribution of green interiors cannot be ignored. As shown in Figure 1, the number of LEED CI projects increased rapidly with other LEED projects in the past decade. Three countries, U.S., China and India, accounted for more than 90\% LEED CI projects, as shown in Table 1.

Insert Figure 1 


\section{Insert Table 1}

The rating systems for interiors aim at three project types: commercial interiors, retails, and hospitality. Office premises are usually the major client for the green interior certification. Many international companies include LEED certification in their corporate sustainability missions. Therefore, when they relocate or open new offices, LEED CI is adopted for showcasing their sustainability commitment. For example, Bloomberg has 17 LEED-CI certified offices. These offices are located in U.S. as well as overseas (Hong Kong, Dubai, Kuala Lumpur, Singapore, London, Mumbai, Oslo, Seoul, Shanghai, etc.). Bank of America is another LEED dedicated company who has more than 17 local and oversea LEED- CI certified offices. CB Richard Ellis has more than 15 LEED CI offices. Many architectural companies such as HOK are actively renovating their local and oversea offices for LEED-CI certification. LEED is seen as an important business strategy for these companies. However, their offices are usually located in a multi-tenant commercial building where they do not have control over the whole building design and major renovation. LEED-CI, therefore, is a sensible choice to guide interior retrofitting to increase employees' work performance, as well as to strengthen the corporate social and business image.

\section{Objective}

Retrofitting usually refers to interventions to adjust, reuse, or upgrade a building to suit new conditions or requirements (Wilkinson, 2012, Mansfield, 2002). Building retrofitting is proved to be an effective intervention to reduce carbon footprint, energy consumptions and improve occupant satisfaction (Forsythe and Wilkinson, 2015, Lo et al., 2014, Atkins and Emmanuel, 2014, Gohardani and Björk, 2012, Miller and Buys, 2008, Baccarini and Bateup, 2008, Kok et al., 2012). Most building retrofitting strategies involve building envelope, Heating Ventilation and Air-conditioning (HVAC) system; renewable energy, lighting, elevators, even building roofs and surroundings (Zhang et al., 2014). However, since most office buildings today are occupied by multi-tenants, tenants usually do not have control over the whole buildings for retrofitting. Interior retrofitting is a common means for tenants to recreate their spaces. Normally, interior retrofitting refers to work of redesigning and reconstructing the existing space in order to incorporate new technologies (e.g. building services, informational and communication technologies) which were not foreseen in the 
original design. Derived from the concept of green building, green building for interiors incorporates a number of strategies covering energy and water efficiency, waste reduction and management, low environmental impact materials, and effective building operation and facility management. It more stresses a life-cycle and multi-scale perspective from urban planning to specific material selection. It is beyond the scope of a normal interior retrofitting project which is usually confined to the indoor space for its spatial function, furnishing and decoration. The question is: to what extent can an interior retrofitting project achieve green building principles such as reducing resource uses and enhancing users' experience? This article is to find out challenges of implementing green building concepts in interior retrofitting projects, based on which opportunities are expected to be found.

\section{Methodology}

To enquire the research question, this article conducts multi-examinations on green building rating systems for interiors and their certified interior projects.

Firstly, green building rating systems for interiors are reviewed and compared to identify what sustainability attributes compose a green building and what are requirements for an interior project to meet the green building principles and targets. Although there are dozens of green building rating systems for new constructions or whole building certifications, few have the systems for interiors. This article selects and compares four major green building rating systems for interiors: U.S. LEED (USGBC, 2013), Hong Kong BEAM Plus (HKGBC, 2013), Australia Green Star (GBCA, 2012), and Singapore Green Mark (BCA, 2012).

Basically, these systems for interiors are based on their main systems for new constructions, with add hoc sustainability attributes for interiors. Their reference guides or technical toolkits are included in this review.

Secondly, LEED CI certified projects are examined in terms of their scorecards, aiming to identify commonalities of these interior retrofitting projects. Examining certified interior projects can help to identify how these projects achieve green building certification and what green design practices are used in the interior retrofitting. Although there are more and more rating systems for interiors being launched for the multi-tenant commercial office building market, LEED is dominant in terms of the number of certified projects. USGBC (U.S. Green 
Building Council) lists out all LEED certified projects in the project directory (http://www.usgbc.org/projects) that is accessible to the public. After sampling and filtering, 27 LEED CI certified projects are selected for analyses (Table 2). The project owners and clients are world top interior design companies who are passionate about showcasing sustainability in their own office design. These projects represent cutting-edge sustainable interior design concepts and technologies. All the selected LEED CI projects are certified according to LEED 2.0. Although there are different versions of LEED for interiors (e.g. LEED CI 1.0, 2.0, 2009 and 4.0), only LEED CI 2.0 certified projects are published with their certification details. These projects are widely distributed across the world, especially in financial cities where interior design is well developed and the market is prosperous.

\section{Insert Table 2}

Last but not least, LEED CI certified offices are surveyed to find out whether the office interiors with green intent can actually enhance occupants' working experience which is one of key objectives of green building principles and is also the main driving factor for tenants to pursue green interiors. This article presents an interview study of three LEED CI Gold offices (Figure 2). The host buildings of the three offices are located in central urban areas. The tenants are three leading architectural companies: HOK, M Moser and NBBJ. The three companies tested their sustainable design ideas and strategies in their offices. The design intent of the three surveyed offices was not only to showcase the firms' dedication to sustainable design but also to create the best work environment for employees, for example, the open-plan layout for maximum outdoor views and daylight penetration, individual task lights, low-emitting materials and so on. Many studies on green building use experience tended to use standard survey methods to investigate the level of comfort or satisfaction (Gou et al., 2012, Baird and Lechat, 2009); while this article mainly presents a focused group interview to understand users' needs and expectations of a sustainable workplace. Five participants from each office were face-to-face interviewed. The interviewees were architects or designers. The interview was semi-structured and conducted in a step-by-step manner so that respondents could reply conveniently. It started from a simple question "Do you know that fact that it is a certified green office?" After that, a number of structured questions were asked. These questions cover indoor environmental qualities such as thermal comfort, 
lighting and acoustics, as well as other issues related to work performance, e.g. facilities, space, behaviour, etc. (Lai and Yik, 2007, Leaman, 1995, Leaman, 1990).

\section{Insert Figure 2}

\section{Green Building Rating Systems for Interiors}

Figure 3 summarises the major categories in each system for interiors. The common categories shared in the four systems are: energy, indoor environment quality, materials. LEED, BEAM Plus and Green Star also include water as a category for interiors. Table 3 compares weightings for these categories in the selected rating systems for interiors. Obviously, Green Mark and LEED give more weighting to Energy; while Green Star and BEAM Plus allocate more weightings to Material. The commonality is that Indoor Environmental Quality (IEQ) is considered equally important in these rating systems.

\section{Insert Figure 3}

\section{Insert Table 3}

The category of Energy usually encourages passive design (natural ventilation and daylightig), high performance building systems (Heating Ventilation and Air-conditioning, abbreviated HVAC), energy management systems (metering and monitoring) and renewable energy uses (photovoltaics, wind turbines, etc.). It rewards projects that reduce the amount of greenhouse gas emissions from operations by addressing issues of energy demand, use efficiency, and supply of energy from alternative sources. The category of Material encourages and rewards interior projects that reduce, reuse and recycle building materials. The majority of materials used in a building are usually sourced outside the site; therefore any effort to reduce imported material contributing to lower environmental impacts is rewarded. The category of Water encourages and rewards initiatives that reduce the interior project's consumption and reliance on potable water. The category assesses the efficiency of projects' fixtures and water reuse strategies, and rewards the substitution of potable water with alternative water sources such as stormwater after being appropriately treated. The category of Indoor Environmental Quality mainly refers to aspects or attributes such as indoor temperature, air quality, lighting, etc., which may impact occupant comfort, health and productivity. The category encourages adopting design strategies that enhance the occupant 
comfort and productivity, and rewards selecting low-emitting interior materials that help reduce indoor pollutants' concentrations. There are other different categories covered in these rating systems. The category of Management included in BEAM Plus and Green Star for interiors encourages and rewards the adoption of sustainable development principles in management practices from design, implementation and operation. The other categories such as Transport, and Land Use and Ecology in Green Star and Location and Transportation in LEED for interiors address the choice of a sustainable base building for hosting the interior project. The category of Innovation is aimed to reward innovative or exceptional performance in sustainable design.

The design of a green building highlights a variety of practices, techniques, and technologies to reduce and ultimately eliminate the impacts of buildings on the environment and human health. In practice, it often advocates planning the site for ecology, locating the project in a dense and well connected urban area, designing open spaces with trees and greenery, designing rain gardens and permeable pavements, using water efficient fixtures, selecting high performance HVAC, lighting and other systems, using renewable resources through photovoltaic panels and wind turbines, selecting low emitting building materials, using building materials from local sources and so on. Some of these green building design practices are within the footprint or boundary of a building; while others are related to a building's interface areas and surroundings. The important fact is that these strategies or interventions are interrelated within the host building in which the interior project is located. The most effective way, obviously, is to select a host building with better sustainability attributes and performance levels in terms of the building's location, design, construction, and management. So, all rating systems encourage the selection of a host building that has been certified as a new construction or major renovation, or alternatively has integrated best practice environmental sustainability measures into its design and daily management. Otherwise, the project designers need assess the host building's performance and find out opportunities for retrofitting to meet the requirements in the green rating systems.

\section{LEED Scorecard Analyses}

Scorecards for these selected projects are collected and compiled. As shown in table 4, the scorecard lists all credits under each category and indicates the achievement of these projects $(\mathrm{N}=27)$. 


\section{Insert Table 4}

Under the category of Site, most interior projects can satisfy the credits for Development Density and Community Connectivity, and Public Transportation Access; while they perform less well on the credits for Bicycle Storage and Changing Rooms, and Parking Availability. This is because most of these offices are located in cities' downtown areas or central business centres (CBD) where buildings are densely planned and well connected to local services and public transits; however, cycling is not encouraged in the planning of these urban central areas and storage and changing rooms for bicycles are seldom considered in the design of these commercial towers. There are only two credits in the category of Water. More than half of these projects satisfy the credits through changing water fixtures for higher efficiency. The credits under the category of Energy show significant variances. The best performance is found on the Energy Star Equipment and Appliances that are under the direct intervention of the project designers by selecting and using Energy Star certified office equipment and appliances; while the worst performance is found on the HVAC Improvements that are not under the direct control and are largely dependent on the host building since most modern office buildings are centrally controlled. Half of the selected interior projects get the credit on Green Power through purchasing electricity from offsite renewable sources instead of adding solar panels or using wind turbines on the site of their projects.

Under the category of Material, most interior projects can develop and implement a construction waste management plan that diverts construction, demolition, and packaging debris from landfill disposal and redirects recyclable recovered resources back to the manufacturing process or appropriate sites. These projects reuse parts of existing furniture and furnishings such as case pieces, seating, filing systems, decorative lighting and accessories; they also use furniture and furnishings with recycled content and building materials that are manufactured within the region. However, few projects maintain interior non-structural components (walls, flooring and ceilings) and less projects use salvaged, refurbished or reused materials (such as beams and posts, flooring, doors and frames, cabinetry, and brick). This is because these interior elements are usually fixed before occupancy and are out of control of the tenant and interior designers. Few projects use rapidly 
renewable materials made from plants that are typically harvested within a short cycle, such as bamboo flooring, wool carpets, straw board, cotton batt insulation, linoleum flooring and others. These projects neither use certified wood based on the Forest Stewardship Council's Principles and Criteria. This is because there are few office furniture or furnishings made from these environmental-friendly materials.

Under the category of Indoor Environmental Quality (IEQ), most projects select low emitting materials such as adhesives, paints, carpets and so on. The interior design makes most seated workstations have direct contact of outdoor views through the open-plan layout. However, few interior projects monitor air delivery and provided individual ventilation control. They also find it difficult to satisfy the requirement on indoor chemicals and pollutant source control that must either employ permanent entryway systems from entering the building or change the ventilation, filtration or drainage systems. These strategies are beyond the design scope of these interior projects if the host buildings are not designed and operated taking into account these requirements. It is interesting to find that even though these interiors have direct outdoor views for most workstations, they can hardly achieve equivalent daylighting performance. The performance of daylighting for an interior depends on three factors: daylight availability on the building envelope, physical and geometrical properties of windows, and physical and geometrical properties of the interior space (Lam, 1977). The open-plan layout and high reflectance furnishing that are used in these interior projects can only maximally utilize the portion of penetrated daylight while it cannot change the daylight availability on the building envelope and windows.

Through analyses of the 27 LEED CI projects and their scorecards, it is found that their achievements on green credits are confined to the direct interventions on interior elements while other green credit achievements are largely dependent on the host building and its urban context. In other words, the green design is rather opportunistic. If the interior project is not appropriately located, many green attributes may not be achieved at any costs or design efforts. For example, because most office buildings are centrally air-conditioned, few green interior projects could be able to improve HVAC performance which would significantly impact indoor environments and energy efficiency. If the office is not appropriately located, it is hard to encourage employees to use bicycles; it is also difficult to acquire daylighting. 


\section{Users' Experience}

Most interviewees were aware of their office certified by LEED and they thought the most appreciable green feature in their offices was abundance of daylight in their workstations. Their specific responses on the indoor environmental qualities as well as work performance are shown in Table 5. They perceived that the daylighting design brought more openness in their offices, which engendered a more collaborative environment. The most positive features that help their work in these certified offices are resulted in by daylighting and open-plan design, too, for collaboration and outdoor views. The lighting retrofitting also successfully provided individual controllability to adjust workstation lighting according to their task performance (computer work or paper work). They also perceived that they were more adaptive since working in their offices. For example, to tackle unstable temperature, they changed their clothing; to avoid distract others, they tended to lower their voices; to be physically in contact with outside, they were more likely to take break for an outside walk. Many negative experiences came from air quality and temperature, which is mainly due to the instability of the centralised HVAC system in the host buildings. Some perceived the glare reflected by the surroundings. Responses on acoustics mainly refer to the much noise from inside due to the open plan layout and air-conditioning operation while less noise from outside because of the sealed building envelope. The negative confirmed with the fact that the environmental performance of interiors such as thermal comfort and air quality, are largely dependent on the host building (Baird et al., 2012, Miller and Buys, 2008), especially when the building is sealed with a central air-conditioning system. Negative experiences also came from lack of space to conduct work. Because most of them are designers who need space to draw and store files. They also tended to be critical of space quality. For example, there is a lack of different scales of space for collaborations. It is interesting to see that respondents unanimously expressed their needs for shower and fitness facilities. These facilities which are of importance to employees' health and well-being, usually can't found in an office building, but can be easily found nearby if the building is appropriately located.

\section{Discussion}

An interior retrofitting project is usually confined to its indoor space; while green building highlights a larger scale environmental assessment covering at least five categories: Site, Water, Energy, Material and Indoor Environmental Quality. Each of these categorises or aspects contain specific credits. To acquire the green building certification, the interior 
project shall meet as many as possible credits under each category. As shown in Figure 4, some of these credits are within the tenant interior space; some are largely dependent on the host building's condition as well as its urban context. Interior designers are primarily associated with the role of interior space design and the selection of finishes, furniture, and fixture that has a significant influence on healthy environments and energy and water efficiencies. However, the wide spectrum of green building rating systems and their design credits requires an interior retrofitting project to look beyond the interior space and also requires tenants and designers to think and operate more strategically. What is the urban context? Whether is it situated in a well-connected urban area with a pedestrian-friendly access to public services, transit and so on? How much daylight available on the building's envelope? What is the building's HVAC system? Whether can the HVAC system be improved in terms of energy performance and indoor pollutants' control? How much can existing furnishings or furniture be maintained? There are many questions posed for an interior project that aims for green building rating and certification. The tenants and designers need to insert themselves in the questioning phase before a project has a clear position. Through the questioning phase, the interior project can wisely choose a host building with better sustainability attributes and performance levels in terms of the building's location, design, construction, and management, which makes the interior retrofitting more effectively minimize its environmental impacts and enhance employee's work experience.

\section{Insert Figure 4}

Through empirical studies of LEED scorecard and interviews, it is obvious that interior retrofitting had limited interventions over the base building and its urban context. For example, few projects could improve their HVAC performance for energy efficiency or air quality, which resulted in negative building occupants' experience according to the interview study. The occupants also reported a lack of amenities in workplaces. If the base building is not designed or operated in an environmental-friendly way or the base building's surroundings are not equipped with facilities, the interiors would fail most key sustainable features. The failure of achieving some significant green credits raised some question marks or critiques for green interior retrofitting projects. Although these designers and clients of these projects are top architecture and interior design companies in the world, their 
retrofitting efforts tended to be low-hanging fruits such as interior fitouts. It needs to be pushed further to embrace more significant green features and credits. On the other hand, these offices are located in prestigious modern office buildings in urban downtown or CBD areas. The failure might also point to a question mark: whether today's office buildings can allow an effective retrofitting? This may refer to some technical issues as well as some rental or lease legislation issues. The effectiveness of green retrofitting should be interrogated in real estate and properties management research.

\section{Conclusion}

The green building credits for interiors fall into three relational layers: the urban context, the host building and interior fitouts. Most projects under study performed well on credits for interior fitouts (e.g. low emitting materials, energy efficient equipment and appliances, etc.) while underperformed on credits for its host building (e.g. air-conditioning systems, ventilation, etc.). The latter might more significantly affect occupant satisfaction. The other aspects such as daylight availability, facilities accessibility might be subject to its location and urban context. If an office is located in a host building designed and managed in an environmental friendly way, especially with high performance Heating Ventilation and Airconditioning system, the energy efficiency and employees' environmental comfort can be easily achieved; furthermore, if the host building is located in urban areas with good connections to public transits and services, the reduction of employees' carbon footprint and needs of facilities can be easily met. So, the host building and its location are most important in the retrofitting process, and should be prioritized in green building rating systems for interiors. This article recommends that tenants should be proactively involved in the early stage of location and host building selection.

The study selected 27 LEED CI offices for a scorecard analysis and 3 LEED CI offices for an interview study. All of them are design companies. The study of their offices is expected to represent most innovative design concepts and strategies. On the other hand, the study might be biased due to the singular sample type, especially for the interview. The obvious bias is that the design professionals might be more critical about space, such as the quantity and quality of space. However, responses to other questions such as temperature, air quality, facilities, and so on are supposed to be based on common office work experience. The article 
suggests that the retrofitting as a strategy to implement green building should be further interrogated from other perspectives such as real estate, property management, etc.

\section{References}

ATKINS, R. \& EMMANUEL, R. 2014. Could refurbishment of "traditional" buildings reduce carbon emissions? Built Environment Project and Asset Management, 4, 221-237.

BACCARINI, D. \& BATEUP, G. 2008. Benefits management in office fit-out projects. Facilities, 26, 310-320.

BAIRD, G., LEAMAN, A. \& THOMPSON, J. 2012. A comparison of the performance of sustainable buildings with conventional buildings from the point of view of the users. Architectural Science Review, 55, 135-144.

BAIRD, G. \& LECHAT, S. 2009. Users' Perceptions of Personal Control of Environmental Conditions in Sustainable Buildings. Architectural Science Review, 52, 108-116.

BCA 2012. Green Mark for Office Interior v1.1. Singapore: Building and Construction Authority.

DERMISI, S. V. 2009. Effect of LEED ratings and levels on office property assessed and market values. Journal of Sustainable Real Estate, 1, 23-47.

FORSYTHE, P. \& WILKINSON, S. 2015. Measuring office fit-out changes to determine recurring embodied energy in building life cycle assessment. Facilities, 33, 262-274.

FUERST, F. \& MCALLISTER, P. 2009. An investigation of the effect of eco-labeling on office occupancy rates. Journal of Sustainable Real Estate, 1, 49-64.

GBCA 2012. Green Star Rating Tool for Interiors v1. Green Building Council Australia.

GOHARDANI, N. \& BJÖRK, F. 2012. Sustainable refurbishment in building technology. Smart and Sustainable Built Environment, 1, 241-252.

GOU, Z., LAU, S. S.-Y. \& PRASAD, D. 2013. Market readiness and policy implications for green buildings: Case study from Hong Kong. College Publishing, 8, 162-173.

GOU, Z., LAU, S. S.-Y. \& SHEN, J. 2012. Indoor Environmental Satisfaction in Two LEED Offices and its Implications in Green Interior Design. Indoor and Built Environment, 21, 503-514.

HKGBC 2013. BEAM Plus Interiors V1.0. Hong Kong: Hong Kong Green Building Council.

HUI, E. C.-M., CHAN, E. W.-F. \& YU, K.-H. 2015. The effect of LEED certification on Shanghai's prime office rental value. Journal of Facilities Management, 13, 297-310.

KOK, N., MILLER, N. \& MORRIS, P. 2012. The Economics of Green Retrofits. Journal of Sustainable Real Estate, 4, 4-22.

KUZIEMKO, J. 2015. LEED buildings outperform market peers according to research. USGBC.

LAI, J. H. K. \& YIK, F. W. H. 2007. Perceived Importance of the Quality of the Indoor Environment in Commercial Buildings. Indoor and Built Environment, 16, 311-321.

LAM, W. M. C. 1977. Perception and Lighting as Formgivers for Architecture, McGraw-Hill. 
LEAMAN, A. 1990. Productivity and office quality. Eacilities, 8, 12-14.

LEAMAN, A. 1995. Dissatisfaction and office productivity. Facilities, 13, 13-19.

LO, K. K., HUI, E. C. M. \& ZHANG, K.-X. V. 2014. The benefits of sustainable office buildings in People's Republic of China (PRC): revelation of tenants and property managers. Journal of Eacilities Management, 12, 337-352.

MANSFIELD, J. R. 2002. What's in a name? Complexities in the definition of "refurbishment". Propertv Management, 20, 23-30.

MILLER, E. \& BUYS, L. 2008. Retrofitting commercial office buildings for sustainability: tenants' perspectives. Journal of Propertv Investment \& Finance, 26, 552-561.

USGBC 2013. LEED Reference Guide for Interior Design and Construction v4. U.S. Green Building Council.

USGBC 2014. Green Building Facts. U.S. Green Building Council.

WILKINSON, S. 2012. Analysing sustainable retrofit potential in premium office buildings. Structural Survev, 30, 398-410.

YUDELSON, J. 2008. The Green Building Revolution, Washington, Island Press.

ZHANG, S., PAN, W. \& KUMARASWAMY, M. 2014. A multi-criteria decision framework for the selection of low carbon building measures for office buildings in Hong Kong. International Journal of Energy Sector Management, 8, 456-476. 
Table 1. Top 3 countries where LEED CI certified projects are located

\begin{tabular}{l|l|l|l}
\hline No. & Area & Number of Projects & Percentage \\
\hline 1 & United States & 3556 & $84.0 \%$ \\
\hline 2 & China & 206 & $4.8 \%$ \\
\hline 3 & India & 133 & $3.1 \%$ \\
\hline \multicolumn{2}{l}{ Accumulated Percentage } & $91.9 \%$ \\
\hline
\end{tabular}

(c) Emerald Group Publishing Limited

This is a pre-print of a paper and is subject to change before publication. This pre-print is made available with the understanding that it will not be reproduced or stored in a retrieval system without the permission of Emerald Group Publishing Limited. 
Table 2. Selected LEED CI projects

\begin{tabular}{|c|c|c|c|c|}
\hline No. & Project & City & $\begin{array}{l}\text { Year of } \\
\text { Certification }\end{array}$ & $\begin{array}{l}\text { Level of } \\
\text { Certification }\end{array}$ \\
\hline 1 & Callison Dallas office & Dallas & 2009 & Certified \\
\hline 2 & Callison New York & New York & 2010 & Gold \\
\hline 3 & GENSLER NEW YORK OFFICE & New York & 2007 & Silver \\
\hline 4 & Gensler - Boston Offices & Boston & 2008 & Gold \\
\hline 5 & Gensler office-Houston & Houston & 2008 & Gold \\
\hline 6 & Gensler London Office & London & 2009 & Silver \\
\hline 7 & Gensler Phoenix Office & Phoenix & 2009 & Silver \\
\hline 8 & Gensler Dallas Office & Dallas & 2008 & Silver \\
\hline 9 & Gensler Seattle Office & Seattle & 2010 & Gold \\
\hline 10 & HDR Architecture San Francisco & San Francisco & 2010 & Silver \\
\hline 11 & HOK Singapore Office & Singapore & 2007 & Silver \\
\hline 12 & HOK Shanghai Office & Shanghai & 2008 & Silver \\
\hline 13 & HOK Chicago Office & Chicago & 2009 & Platinum \\
\hline 14 & HOK Miami Office & Miami & 2010 & Certified \\
\hline 15 & HOK HK Office & Hong Kong & 2009 & Gold \\
\hline 16 & M Moser Guangzhou Office & Guangzhou & 2009 & Gold \\
\hline 17 & M Moser Hong Kong Office & Hong Kong & 2009 & Gold \\
\hline 18 & NBBJ Seattle Office & Seattle & 2007 & Gold \\
\hline 19 & NBBJ LA Office & Los Angeles & 2009 & Silver \\
\hline 20 & SmithGroup - San Francisco Office & San Francisco & 2009 & Gold \\
\hline 21 & SOM Chicago Office & Chicago & 2009 & Silver \\
\hline 22 & Flad Architects Atlanta Office & Atlanta & 2010 & Gold \\
\hline 23 & DLR Group - MSP Office & Minneapolis & 2010 & Certified \\
\hline 24 & EwingCole Philadelphia Office & Philadelphia & 2008 & Gold \\
\hline 25 & Vocon Cleveland Office & Cleveland & 2010 & Gold \\
\hline 26 & Space Matrix New Delhi Office & New Delhi & 2010 & Platinum \\
\hline 27 & RTKL Chicago Office & Chicago & 2008 & Silver \\
\hline
\end{tabular}


Table 3. Aspects covered in each green building rating systems for interiors

\begin{tabular}{|c|c|c|c|}
\hline $\begin{array}{l}\text { Hong Kong BEAM } \\
\text { Plus }\end{array}$ & $\begin{array}{l}\text { Australia Green } \\
\text { Mark }\end{array}$ & $\begin{array}{l}\text { Singapore Green } \\
\text { Star }\end{array}$ & $\begin{array}{l}\text { U.S. } \\
\text { LEED }\end{array}$ \\
\hline $\begin{array}{ll}\text { - } & \text { Green Building } \\
\text { - } & \text { Attributes } \\
\text { - } & \text { Management } \\
\text { - } & \text { Energy Use } \\
\text { - } & \text { Water Use } \\
\text { - } & \text { Indoor } \\
\text { Environmental } \\
\text { - } \text { Quality } \\
\text { Innovation }\end{array}$ & $\begin{array}{ll}\text { - } & \text { Energy Efficiency } \\
\text { - } & \text { Water Efficiency } \\
\text { - } & \text { Sustainable } \\
\text { Management } \\
\text { and Operation } \\
\text { - Indoor } \\
\text { Environmental } \\
\text { Quality } \\
\text { - Other Green } \\
\text { Features }\end{array}$ & $\begin{array}{ll}\text { - } & \text { Management } \\
\text { - } & \text { Indoor } \\
& \text { Environmental } \\
& \text { Quality } \\
\text { - } & \text { Energy } \\
\text { - } & \text { Transport } \\
\text { - } & \text { Water } \\
\text { - } & \text { Materials } \\
\text { - } & \text { Land Use and } \\
& \text { Ecology } \\
\text { - Emissions } \\
\text { - Innovation }\end{array}$ & $\begin{array}{ll}\text { - } & \text { Integrative Process } \\
\text { - } & \text { Location and } \\
\text { - } & \text { Wransportation } \\
\text { - } & \text { Energy Efficiency } \\
\text { Atmosphere } \\
\text { - } \text { Material and } \\
\text { - Resources } \\
\text { Indoor } \\
\text { Environmental } \\
\text { - } \text { Inuality } \\
\text { - } \text { Regionovation Priority }\end{array}$ \\
\hline
\end{tabular}


Table 4. The LEED scorecard and project achievements

\begin{tabular}{|c|c|c|c|c|}
\hline \multirow[t]{2}{*}{ Aspects } & \multirow[t]{2}{*}{ Credits } & \multirow[t]{2}{*}{ Requirements } & \multicolumn{2}{|c|}{$\begin{array}{l}\text { Projects that get } \\
\text { the credit }(\mathrm{N}=27)\end{array}$} \\
\hline & & & Number & Percent \\
\hline \multirow[b]{2}{*}{ Sustainable } & Credit 1 & Site Selection & 20 & $74 \%$ \\
\hline & Credit 2 & $\begin{array}{l}\text { Development Density and Community } \\
\text { Connectivity }\end{array}$ & 26 & $96 \%$ \\
\hline \multirow{3}{*}{ Sites } & Credit 3.1 & Public Transportation Access & 26 & $96 \%$ \\
\hline & Credit 3.2 & Bicycle Storage \& Changing Rooms & 10 & $37 \%$ \\
\hline & Credit 3.3 & Parking Availability & 17 & $63 \%$ \\
\hline \multirow{2}{*}{$\begin{array}{c}\text { Water } \\
\text { Efficiency }\end{array}$} & Credit 1.1 & Water Use $20 \%$ Reduction & 18 & $67 \%$ \\
\hline & Credit 1.2 & Water Use $30 \%$ Reduction & 15 & $56 \%$ \\
\hline \multirow{14}{*}{$\begin{array}{c}\text { Energy \& } \\
\text { Atmosphere }\end{array}$} & Credit 1.1a & Lighting Power 15\% Below Standard & 18 & $67 \%$ \\
\hline & Credit $1.1 \mathrm{~b}$ & Lighting Power 25\% Below Standard & 15 & $56 \%$ \\
\hline & Credit $1.1 \mathrm{c}$ & Lighting Power 35\% Below Standard & 8 & $30 \%$ \\
\hline & Credit 1.2 & Lighting Controls & 15 & $56 \%$ \\
\hline & Credit $1.3 \mathrm{~A}$ & HVAC Equipment Efficiency & 9 & $33 \%$ \\
\hline & Credit 1.3A & HVAC Appropriate Zoning Controls & 1 & $4 \%$ \\
\hline & Credit 1.3B & HVAC $15 \%$ Improvement & 2 & $7 \%$ \\
\hline & Credit 1.3B & HVAC 30\% Improvement & 0 & $0 \%$ \\
\hline & Credit $1.4 \mathrm{a}$ & Equipment \& Appliances 70\% Energy Star & 24 & $89 \%$ \\
\hline & Credit $1.4 \mathrm{~b}$ & Equipment \& Appliances 90\% Energy Star & 21 & $78 \%$ \\
\hline & Credit 2 & Enhanced Commissioning & 7 & $26 \%$ \\
\hline & Credit 3a & Energy Use Sub-metering & 15 & $56 \%$ \\
\hline & Credit 3b & Energy Costs Paid by the Tenant & 15 & $56 \%$ \\
\hline & Credit 4 & Green Power & 14 & $52 \%$ \\
\hline \multirow{7}{*}{$\begin{array}{l}\text { Materials \& } \\
\text { Resources }\end{array}$} & Credit 1.1 & Tenant Space Long-Term Commitment & 16 & $59 \%$ \\
\hline & Credit 1.2 & $\begin{array}{l}\text { Maintain } 40 \% \text { of Interior Non-Structural } \\
\text { Components }\end{array}$ & 7 & $26 \%$ \\
\hline & Credit 1.3 & $\begin{array}{l}\text { Maintain } 60 \% \text { of Interior Non-Structural } \\
\text { Components }\end{array}$ & 6 & $22 \%$ \\
\hline & Credit 2.1 & Divert $50 \%$ Construction Waste From Landfill & 21 & $78 \%$ \\
\hline & Credit 2.2 & Divert $75 \%$ Construction Waste From Landfill & 17 & $63 \%$ \\
\hline & Credit 3.1 & 5\% Resource Reuse & 4 & $15 \%$ \\
\hline & Credit 3.2 & $10 \%$ Resource Reuse & 3 & $11 \%$ \\
\hline
\end{tabular}




\begin{tabular}{|c|c|c|c|c|}
\hline & Credit 3.3 & $30 \%$ Furniture and Furnishings Reuse & 17 & $63 \%$ \\
\hline & Credit 4.1 & $10 \%$ Recycled Content & 20 & $74 \%$ \\
\hline & Credit 4.2 & $20 \%$ Recycled Content & 15 & $56 \%$ \\
\hline & Credit 5.1 & $20 \%$ Materials Manufactured Regionally & 19 & $70 \%$ \\
\hline & Credit 5.2 & $\begin{array}{l}\text { 10\% Materials Extracted and Manufactured } \\
\text { Regionally }\end{array}$ & 8 & $30 \%$ \\
\hline & Credit 6 & Rapidly Renewable Materials & 3 & $11 \%$ \\
\hline & Credit 7 & Certified Wood & 3 & $11 \%$ \\
\hline & Credit 1 & Outdoor Air Delivery Monitoring & 4 & $15 \%$ \\
\hline & Credit 2 & Increased Ventilation & 11 & $41 \%$ \\
\hline & Credit 3.1 & $\begin{array}{l}\text { Construction IAQ Management Plan During } \\
\text { Construction }\end{array}$ & 21 & $78 \%$ \\
\hline & Credit 3.2 & $\begin{array}{l}\text { Construction IAQ Management Plan Before } \\
\text { Occupancy }\end{array}$ & 11 & $41 \%$ \\
\hline & Credit 4.1 & Low-Emitting Adhesives \& Sealants & 23 & $85 \%$ \\
\hline & Credit 4.2 & Low-Emitting Paints and Coatings & 27 & $100 \%$ \\
\hline & Credit 4.3 & Low-Emitting Carpet Systems & 25 & $93 \%$ \\
\hline Environmental & Credit 4.4 & $\begin{array}{l}\text { Low-Emitting Composite Wood and Laminate } \\
\text { Adhesives }\end{array}$ & 14 & $52 \%$ \\
\hline & Credit 4.5 & Low-Emitting Systems Furniture and Seating & 15 & $56 \%$ \\
\hline & Credit 5 & Indoor Chemical \& Pollutant Source Control & 4 & $15 \%$ \\
\hline & Credit 6.1 & Controllability of Lighting & 16 & $59 \%$ \\
\hline & Credit 6.2 & Controllability of Temperature and Ventilation & 4 & $15 \%$ \\
\hline & Credit 7.1 & Thermal Comfort Compliance & 21 & $78 \%$ \\
\hline & Credit 7.2 & Thermal Comfort Monitoring & 15 & $56 \%$ \\
\hline & Credit 8.1 & Daylight $75 \%$ of Spaces & 16 & $59 \%$ \\
\hline & Credit 8.2 & Daylight $90 \%$ of Spaces & 10 & $37 \%$ \\
\hline & Credit 8.3 & Views for $90 \%$ of Seated Spaces & 26 & $96 \%$ \\
\hline
\end{tabular}


Table 5. Main responses to the interview

\begin{tabular}{|c|c|}
\hline Questions & Main Responses \\
\hline Air quality & $\begin{array}{l}\text { - } \text { Not enough fresh air } \\
\text { - The air is a little stuffy } \\
\text { - Ventilation is ineffective }\end{array}$ \\
\hline Thermal Comfort & - The temperature is always too cold or too cold \\
\hline Lighting/Daylighting & $\begin{array}{l}\text { - Discomfort glare during morning makes it hard to focus on screen } \\
\text { - Lots of natural light } \\
\text { - Reflected glare from outside } \\
\text { - Too much sun during the day, not enough light at night } \\
\text { - Artificial lighting is unchanged day and night, and it needs more } \\
\text { natural variety }\end{array}$ \\
\hline Acoustics & $\begin{array}{l}\text { - Noise from nearby colleagues when they are on the phone } \\
\text { - Noise from air-conditioning and ventilation. } \\
\text { - Too much noise from inside and no noise at all from outside makes me } \\
\text { feel disconnected }\end{array}$ \\
\hline Space at work & $\begin{array}{l}\text { - Larger desk space is needed to accommodate sketching/drawing } \\
\text { requirements } \\
\text { - Lack of filing and storage space } \\
\text { - Potential storage space on and below that desk has not been fully } \\
\text { utilised }\end{array}$ \\
\hline Meeting Space & $\begin{array}{l}\text { - } \\
\text { - } \\
\text { - } \\
\text { - Lack of small meeting rooms for } 2-4 \text { people } \\
\text { accommodate different needs }\end{array}$ \\
\hline Ergonomics & $\begin{array}{l}\text { - Table height and chair is only suited for a taller person } \\
\text { - Chairs are not ergonomically for tall people }\end{array}$ \\
\hline Facilities & $\begin{array}{l}\text { - } \\
\text { - }\end{array}$ \\
\hline Things that help work & $\begin{array}{l}\text { - } \\
\text { - } \text { Adjacency to other team members } \\
\text { - } \quad \text { Abundance of natural light and lots of windows to look out } \\
\text { - } \quad \text { Task lighting control } \\
\text { - } \text { Good workstation for computer work }\end{array}$ \\
\hline
\end{tabular}




\begin{tabular}{|c|c|}
\hline Things that hinder work & $\begin{array}{l}\text { - } \\
\text { - Excessive sunlight experience in the morning with the translucent } \\
\text { blinds } \\
\text { - Lack of desk space for filing and drawing } \\
\text { - Noise and distraction } \\
\text { - Stuffy air } \\
\text { - No control over air-conditioning and operable windows }\end{array}$ \\
\hline Change of behaviours & 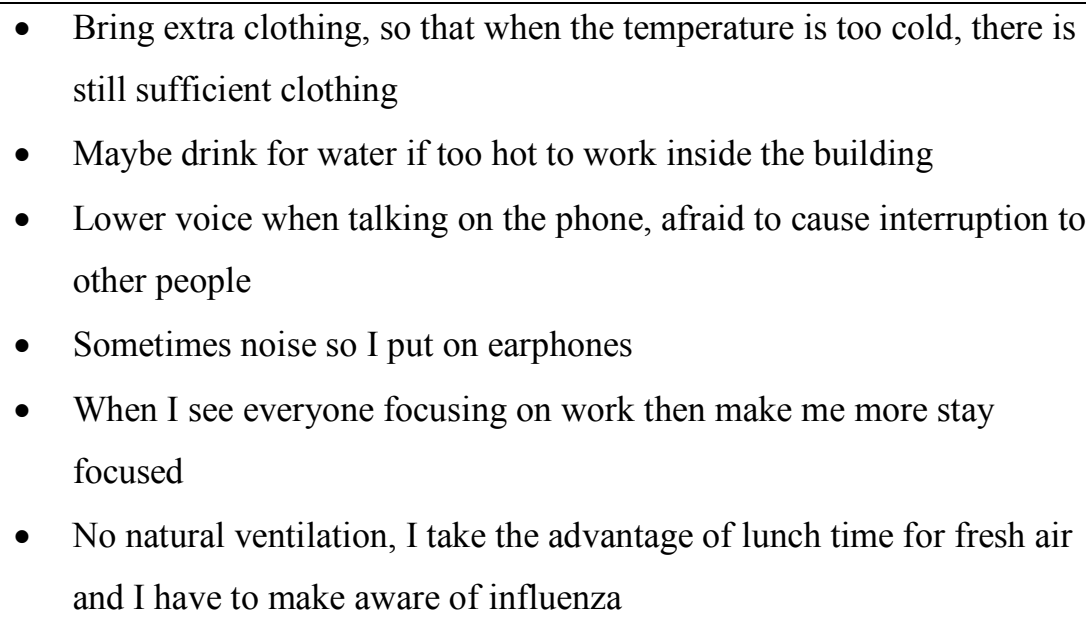 \\
\hline
\end{tabular}




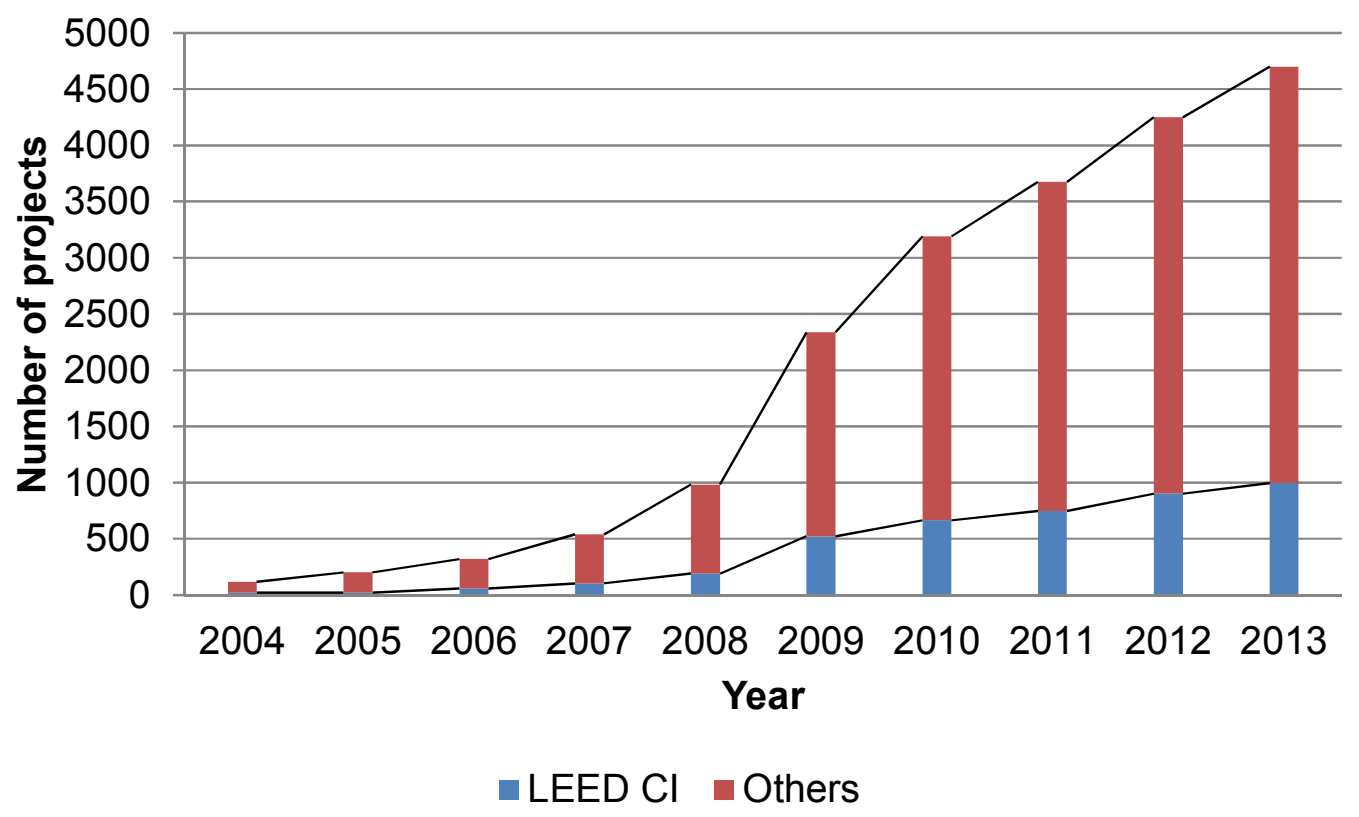

Figure 1. Numbers of LEED CI certified projects in the past decade

(c) Emerald Group Publishing Limited

This is a pre-print of a paper and is subject to change before publication. This pre-print is made available with the understanding that it will not be reproduced or stored in a retrieval system without the permission of Emerald Group Publishing Limited. 


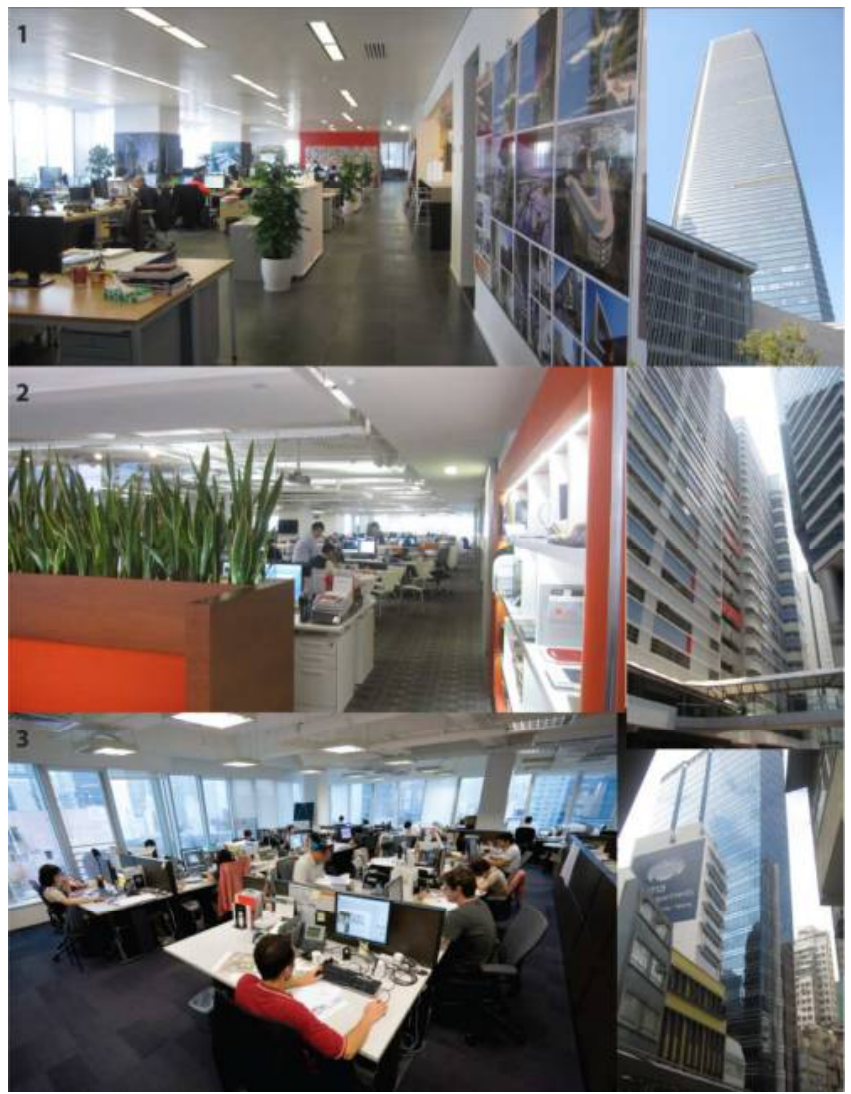

Figure 2. Three LEED CI offices (1. NBBJ Shanghai Office; 2. M Moser Hong Kong Office;

3. HOK Hong Kong Office). All photos taken by the author.

(c) Emerald Group Publishing Limited

This is a pre-print of a paper and is subject to change before publication. This pre-print is made available with the understanding that it will not be reproduced or stored in a retrieval system without the permission of Emerald Group Publishing Limited. 


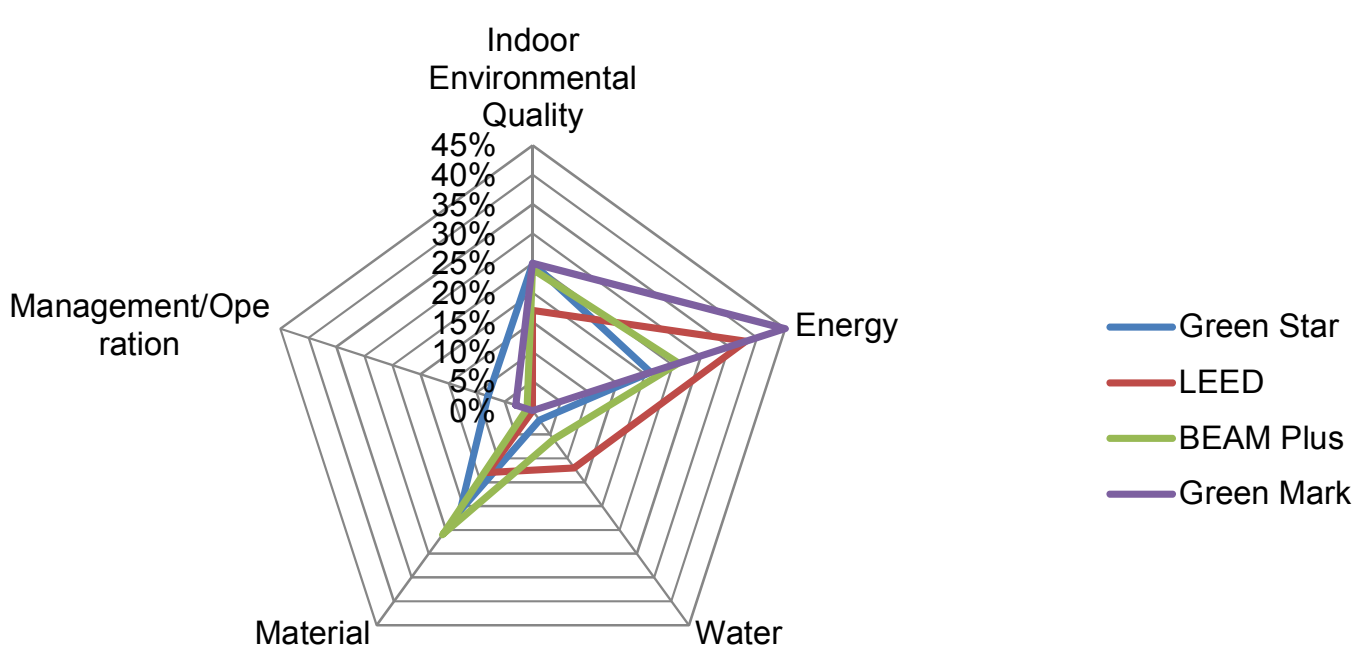

Figure 3. Weightings of the five major categories

(c) Emerald Group Publishing Limited

This is a pre-print of a paper and is subject to change before publication. This pre-print is made available with the understanding that it will not be reproduced or stored in a retrieval system without the permission of Emerald Group Publishing Limited. 


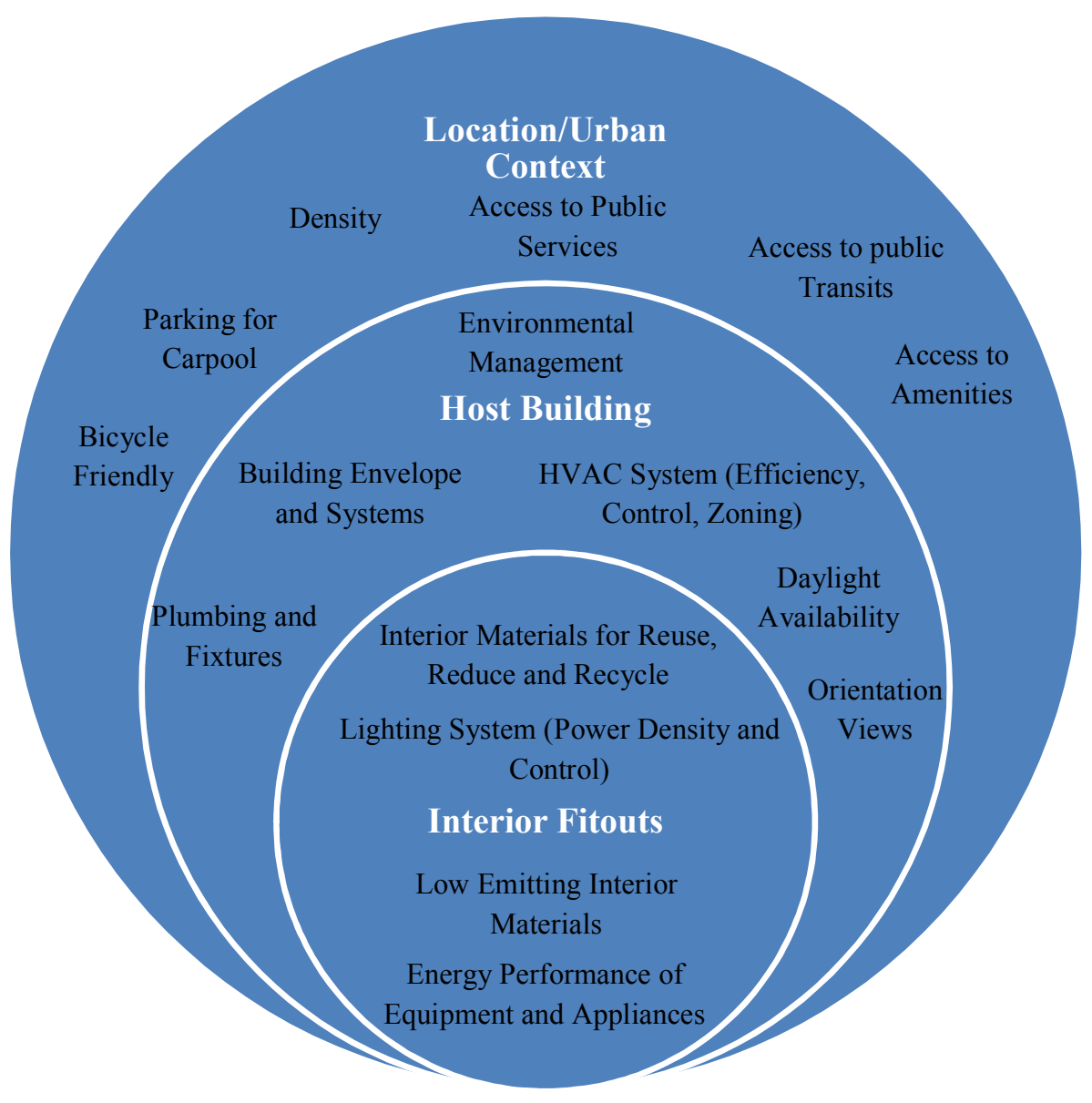

Figure 4 . The spectrum of green building credits for interiors

(c) Emerald Group Publishing Limited

This is a pre-print of a paper and is subject to change before publication. This pre-print is made available with the understanding that it will not be reproduced or stored in a retrieval system without the permission of Emerald Group Publishing Limited. 